\title{
TO KNOW NOTHING: APOPHATIC THEOLOGY IN THE DIONYSIAN CORPUS
}

\begin{abstract}
The article briefly shows the major points of apophaticism in Pseudo-Dionysius, focusing on his stances of the incomprehensibility of God (the One, the Supreme Cause of everything, Being itself) and the limitations to men's abilities of attaining any proper knowledge about his immeasurable greatness and infinite power. In an attempt at a brief overview of some of the aspects of his apophatic theology, chosen passages from the treatises The Divine Names, The Celestial Hierarchy and the Mystical Theology (as well as from two of his Letters) show his insistence on the ineffability and the incomprehensibility of God, the knowledge of him as limited to an experience of his manifestation in the world, and the non-knowledge achieved through denial of everything of this world including oneself, and the understanding that nothing can be affirmed or denied of God.
\end{abstract}

Negation relates one expression to another with a meaning that is (in some way) opposed. ${ }^{1}$ There is a certain openness to negation: if it is not contained and specified, non- $x$ can be anything that is not $x$. The starting point of apophaticism may suffer from inner inconsistency: to negate $x$, or certain aspects of it, there has to be a minimum knowledge of what $x$ is, so it can be denied that it is, in fact, it (or like that). When one does not know God, because of God's ontological superiority, his being way beyond the profane realm of man's cognitive capabilities, how much of God does (not) one know? The negation of knowledge about

${ }^{1}$ Aristotle defines negation (apophasis) as a statement of something away from another (affirmation, kataphasis, being a statement affirming one thing or another, On Interpretation $17 \mathrm{a} 25$ ). Aristotle also attributes less value to negative propositions: the affirmative proposition is prior to and better known than the negative (affirmation explains denial just as being is prior to not-being, Metaphysics 996b14-16).

${ }^{2}$ The negative approach is not merely a way into the positive through elimination, in the sense that one denies everything that can plausibly be denied, and what remains must be affirmed, but is an approach on its own, significant because of its characteristics and implications. Sometimes through the negative way affirmations are reached, and sometimes sublations; vice-versa, affirmations may lead to negations, if their informative, epistemological and ontological value is deemed insufficient. Negation can be utilised in order to affirm the impossibility to affirm. Certain forms of negation serve to lead to affirmations of super-abundance (of a quality, characteristic, being), in which case not $x$ is not in the sense of too much $x$. 
God (or First Principle, Supreme Cause of Everything, the One, Being itself) can be due to the acknowledgement of God's overwhelming and incomprehensible essence, his veiled nature, and the fact that we know him only through his manifestation in our world, through the theophanies we experience, the energies exteriorised in our reality. The lack of knowledge is at times achieved through attempts at affirmations, in which the impossibility to fully and suitably grasp the immeasurable greatness of God's attributes is understood. In concepts in which God's being is ineffable, it can be explained as such due to our ineptitude to comprehend and express anything beyond the limitations of our language and the sphere of ordinary experiences. The extraordinary nature of the experience of God leaves us at a loss of what to utter, how to express, what names to properly use. Moreover, if consistently brought forward, this ineffability leads to not-even-ineffability (if God is ineffable, we do not really know to what extent we are ignorant and speechless, therefore we might as well resign to a not-even-ineffable God/Being/First Principle/Supreme Cause). The negative (apophatic) approach in theology is inseparable from the affirmative (cataphatic); they both apply to God (the One), and represent the direction of the intellect's understanding of God. God's revelation to man may lead to affirmations of him; while negations about what is manifest of God, by transcending what is revealed of him, represent a move beyond knowledge about God, and toward God itself.

The universe in its origin, constituents and structure is simultaneously monadic and triadic in the system of Pseudo-Dionysius (the Areopagite). ${ }^{3}$ The Dionysian corpus, propounding his conception of theology as a methodological science of God, consists of the four extant treatises: On the divine names, On Mystical theology, On the celestial hierarchy, On the ecclesiastical hierarchy ${ }^{4}$ and ten Epistles. If God is conceived as all things in all things, he can be spoken about, but if he, by way of his super-worldliness and overwhelming being is not conceived as a thing among things, then, he cannot be spoken about. In his essence (ousia) or unity (henosis), God is unknowable - from here the distinction between the two approaches begins to function. ${ }^{5}$ Apophatic theology

${ }^{3}$ The issue of authorship will not be addressed here, nor will the questions of his adherence to Neo-Platonism, or the confluences and divergences between Neo-Platonic ontology and his Christian theology, which, while pertinent to the apophatic approaches, would lead to multiple vaguely co-related philosophical digressions.

${ }^{4}$ Further abbreviated as $D N, M T, E H, C H$, respectively. Chronologically, the $D N$ might have been an introduction to the whole opus, which places the $M T$ after it, while the $E H$ might have followed the $C H$. The $D N$ also contains references to and resumés of two lost (less likely fictitious) treatises, The Theological Representations and The Symbolic Theology (in the first chapter of $D N$; the former is mentioned also in MT III), which means that they would have preceded it.

${ }^{5}$ God is above all that is something, so nothing can be said about him; God is beyond words. It should be noted that the names Pseudo-Dionysius gives in his affirmative approach are for the most part about God's manifestations, not God itself, so they should be conceived as symbolic titles for God for us. The positive and negative 
is presented in the treatises $M T, C H$ (II, 3), and, although mainly taken as a stellar example of affirmative theology, $D N(\mathrm{I}, 4,5,6$; VII, 1, 3, and XIII, 3), as well as in Letters One and Five. ${ }^{6}$ Theology is the word of

approaches are part of Pseudo-Dionysius' three different theologies: affirmative (cataphatic), symbolic, and mystical (where the apophatic theology belongs). Apart from the commonly considered two approaches, some authors suggest a wider interpretation of the two theologies which broadens into four: affirmative, symbolic, negative and mystical, although Dionysius himself does not make this distinction formally, see Deirdre Carabine, The Unknown God (Louvain: Peeters Press, 1995), 287. Sheldon-Williams interprets affirmative theology as the science of God as efficient cause (cause can be named from effect), symbolic theology as the science of God as final cause (epistrophê), and mystical (negative) theology as the science of God as monê - I. P. SheldonWilliams, "The Greek Christian Platonist Tradition from the Cappadocians to Maximus and Eriugena", in A. H. Armstrong, Ed. The Cambridge History of Later Greek and Early Medieval Philosophy (Cambridge: Cambridge University Press, 1967), 460. He succinctly explains that the entire Dionysian corpus falls into three parts, corresponding to the three aspects of the Thearchy - a term employed presumably because it combines the notions of plurality and singularity, and also because God itself is merely one of the Names of God: the cataphatic, symbolic, and mystical theologies. See also Jan Vanneste, Le mystère de Dieu - Essai sur la structure rationelle de la doctrine mystique du Pseudo-Denys l'Aréopagite (Desclée de Brouwer: Brussels, 1959), 24. The cataphatic theology, subject of the $D N$, is the science of God as proodos or Efficient Cause of the Forms, and also because the Forms are the attributes which are affirmed of God. The symbolic theology, covered in a lost treatise of this name, and the two Hierarchies and Letter Nine, is the science of God as epistrophe or Final Cause, to Whom it ascends through sensible and intelligible symbols. The mystical theology, subject of the eponymous treatise and Letter Five (and Letter One) is the science of God as monê, immutably inaccessible to sense and intellect. Each theology falls into three sections, further explains Sheldon-Williams: the cataphatic deals with the Good, the Intelligible Triad; the symbolic with the legal, ecclesiastical and celestial hierarchies; the mystical proceeds by the apophatic method, denying that the affirmations applied to God in the cataphatic method are relevant to God as transcendent, through agnosia, the unknowing of the Unknowable, to henosis, the super-intelligible union with God. The symbolic and mystical theologies are anagogic, through catharsis, illumination, and unification, I. P. Sheldon-Williams, "The Greek Christian Platonist Tradition from the Cappadocians to Maximus and Eriugena", 460.

Although aware that Thomas Aquinas does not formally delineate three different kinds of theological negation, Rocca proposes three types of negation detectable in his opus, which he calls qualitative (total denial of any characteristic or property of God), objective modal (denies the creaturely objective mode of a perfection to God), and subjective modal negation (denies the usual ways humans use to think of and determine divine characteristics, due to the manner humans use propositions), Gregory P. Rocca, Speaking the Incomprehensible God (Washington: The Catholic University of America Press, 2004), 58. It is curious whether Pseudo-Dionysius' different negations could be fitted into these proposed groups, as he is certainly expressive about the limitations of men's thinking and expressing of that which is beyond their capabilities, denies even the being of God, and thus the creaturely objective mode of a perfection to God (albeit allowing for perfection itself to be affirmed of God), and he is as radical about denial of attributes or anything of God in $M T$.

${ }^{6}$ Losskiy finds that, unlike the Neo-Platonists and Origen, for whom negative theology does not oppose positive theology, serving the way towards union with the One (which, as such, can be cataphatically determined), Pseudo-Dionysius denies any possibility to determine God, even the character of the object of knowing or non-knowing 
God, ${ }^{7}$ and a tool for perusing Scripture, which is a form of divine manifestation. The truth about the divine essence is confined in Scripture, and through it one gets lifted up to the divine simplicity itself. ${ }^{8} \mathrm{He}$ explains that Celestial Hierarchies are to be celebrated as they are revealed in the Scriptures, with the caveat that theology, in its sacred utterances concerning the formless Intelligences, does indeed use poetic symbolism, as it must hold in regard the constraints of human intelligence, and provide a means of ascent fitting and natural to it, by framing the sacred Scriptures in a manner designed for proper upliftment. ${ }^{9}$ Beings are

(Владимир Н. Лосский, “Апофатическое богословие в учении святого Дионисия Ареопагита”, Богословские труды, (1985, Но. 26): 164. However, Losskiy finds that, on the other hand, unlike Clement of Alexandria and the great Capadoccians, he insists on the real meaning of divine names, thus positing an obvious cataphatic approach. It is important to remember that this supposed opposition of affirmative and negative approaches is a dialectical tool, and that Pseudo-Dionysius' work functions as a unity.

The distinction between unions and differentiations in God (which will be briefly dealt with later in this text), may also be a way to parsing the two approaches, along with the concepts of the hidden God and the revealed God. It is important to see Pseudo-Dionysius' take on divine union and differentiation, along with his distinctions between the hidden essence (ousia or hypraxis) and the manifestation though exteriorised energies (the distinction between God himself and God in the world) as one that recalls or foreshadows (depending where we locate it as full-fledged) the distinction between the essence and energies of God found in Byzantine (and modern Orthodox) theology.

7 DN II, 1 (637A) - all citations are from Colm Luibheid, trans., PseudoDionysius: the Complete Works (New York-Mahwah: Paulist Press, 1987) in [Treatise (chapter, section)] format, followed by the [column numbers and letters] taken from the Corderius edition in Migne.

${ }^{8} \mathrm{He}$ holds the truth of the things concerning God as demonstration of the Spiritmoved power of the theologians, through which it is possible to come into contact with things unutterable and unknown, in a manner unutterable and unknown. As a strict limitation, by no means is it permitted to speak anything concerning the superessential and hidden Deity, anything beyond those things divinely revealed to us in the sacred scripture. Pseudo-Dionysius pairs a portion of his understanding of the Logos with his insistence of the importance of Scripture: in Scripture God almighty is celebrated as "Logos", because he is provider of reason, mind and wisdom, and because he anticipates the causes of all, in Himself, pervades all, is superessential, DN I, 1 (588A).

${ }^{9} \mathrm{DN}$ I, 1 (588A). Hick draws some attention to the direct contradiction in which Pseudo-Dionysius has landed when he says that the Godhead is absolutely ineffable, transcending all our human categories of thought, and that the Godhead is revealed in Scripture as a trinity (one person of whom becomes incarnate). Hick also reminds us that Pseudo-Dionysius seems fully aware of this, and that his answer is that the language of scripture is metaphorical - the Word of God makes use of poetic imagery, John Hick, "Ineffability”, Religious Studies, Vol. 36, No. 1 (Mar., 2000): 38-39.

This way towards unity is a journey of logos upwards, CH II, 1 (117A). Since the superior divine reality is not to be spoken of, Pseudo-Dionysius suggests to look as far upward as the light of sacred Scripture allows, drawn toward the divine splendour in a reverent awe of what is divine. If we may trust the truth and wisdom of Scripture, we should also remember that the attributes of God are revealed to each mind in proportion to its capacities (the immeasurable and infinite is dealt out in limited, appropriate measures).

$\mathrm{CH}$ and $\mathrm{EH}$ are related to $\mathrm{MT}$ - as anagogical, or uplifting interpretations with an awareness of relative incongruity, they amplify the author's references to a return to 
surpassed by the infinity beyond being, and intelligences by the oneness which is beyond intelligence, continues Pseudo-Dionysius. He labels the One as inscrutable, out of reach for any rational process. No words can come up to this inexpressible good, Source of all unity, supra-existent being. Gathered up by no discourse, no intuition, no name, it is the cause of all existence and therefore transcends existence. He reiterates that we must not apply words or conceptions to this hidden transcendent God, unless Scripture-disclosed (as it has taught us that the direct contemplation and understanding of that which surpasses being is inaccessible to beings). The divinity, Scripture instructs, is not only invisible and incomprehensible, but also unsearchable and inscrutable, since there is not a trace for anyone who would reach through, into the hidden depths of this infinity. The Good is not absolutely incommunicable to everything, though, as it grants enlightenment proportionate for every being. ${ }^{10}$

In exploring divine names, Pseudo-Dionysius tries to explain divine unification and differentiation. The fully initiated in the theological tradition to which he adheres, assert that divine unities are hidden and permanent, a realm more than ineffable (it is curious whether he means it in a Basilidean mode of not-even-ineffableness), and more than unknowable; furthermore, the undividable Trinity holds within a shared undifferentiated unity its supra-essential subsistence, supra-divine divinity, supra-excellent goodness, as well as its ineffability, unknowability, many names etc. Pseudo-Dionysius reacts to this with examples of household lighting solutions (all lamps cast all-penetrating light, and yet each is clearly distinct), trying to show that there is distinction in unity and unity in distinction. ${ }^{11}$

The divine differentiations refer to the goodly processions of the supreme Godhead, to its manifestations, by overflowing with goodness,

God through negations, Rorem notices. Anagogy and return are the same upward journey, at least in its first stages, thus integrating the author's concern for biblical and liturgical interpretation into his philosophical structure of procession and return, Paul Rorem, Pseudo-Dionysius - A Commentary on the Texts and an Introduction to Their Influence (New York-Oxford: Oxford University Press, 1993), 209.

${ }^{10} \mathrm{DN}$ I, 1-2 (588B). Rocca remarks that, like in this passage, Pseudo-Dionysius sometimes equates aphairesis and apophasis: both can refer to negative propositions, or to affirmative propositions using predicates prefixed by the alpha privative (other clear examples can be found in the strong passage of $M T 1040 \mathrm{D}$, where he depicts the Supreme Cause as speechless, mindless, but also inexistent, lifeless; as immaterial, shapeless, atopical, without quality, quantity, changes, decays or divisions, without disturbances and deprivations). Rocca underlines that this type of discourse (explicit in Pseudo-Dionysius) states that we should not assume that the negations (apophaseis) are simply the opposites of the affirmations (kataphaseis), but rather that the cause of all is considerably prior to this, beyond privations, beyond every denial (aphairesis), beyond every assertion (thesis), Rocca, Speaking the Incomprehensible God, 18.

${ }^{11} \mathrm{DN}$ II, 4 (640D-641B). One of the properties of this "union" is its superessentiality. It is a sustaining source, a super-divine deity, goodness beyond good, Oneness above source of one; it is unspeakable, much-speaking, the Agnosia. 
revealing and multiplying in a sense - God is superessentially Being, which gives being to things, and produces the whole essences. Remaining undiminished, One in multiplicity, Unified during the progression, complete in the distinction, as it is both superessentially exalted above all, and by begetting everything, God is undivided in things divided, unified in Himself, both unmingled and unmultiplied in the many. ${ }^{12}$ These include the distinctions between the persons within the Trinity, them being an example of differentiation in unity, as a unity - a source of oneness, relating to the divine unity in a modality unlike any other multiplicity. ${ }^{13}$ God is differentiated and multiplied as well, as he imparts being, life, wisdom and many other gifts of his all-creative goodness. Characteristic of the whole divinity is that the entire wholeness is participated in by each of those who participate in it, none participates in only a part - like the centre of the circle shared by all the radii, or the impressions of a single seal that participate in the prototype. ${ }^{14}$ Theological tradition, as he established, helps in distinguishing unity and differentiation. In addressing the names that express the distinctions - the transcendent name and proper activity of the Father, the Son and the Spirit, he stresses that here the titles cannot be interchanged, nor held in common. ${ }^{15}$ Theology, therefore, in dealing with what is beyond being, resorts to differentiation, in the sense that the attributes of the transcendentally divine generation are not interchangeable (the father being the only source of the Godhead which is truly beyond being, which spares

${ }^{12} D N$ II, 11 (649B).

${ }^{13}$ DN II, 4 (641 A-C).

${ }^{14} \mathrm{DN}$ II, 5 (644A). Assuming that the created creatures do participate in the divine perfection, or paradigms, preexisting as a unity in God, and producing creaturely essences; he calls "exemplars" the principles which pre-exist in God as a unity, and produce the essences of things, $D N \mathrm{~V}, 8(824 \mathrm{C})$.

${ }^{15} \mathrm{DN}$ II, 2 (640C). Pseudo-Dionysius, as it can be gathered, introduces a distinction between union (henosis) and differentiation (diakrisis): some names of God have to do with union ("are unified"), others have to do with differentiation ("are differentiated"). The unified names (being, unity, goodness) are applicable to the whole Godhead; they apply equally to each of the Persons of the Trinity (as shown in $D N$ II, 3640C), while the differentiated names (Father, Son and Holy Spirit) do not apply to the whole Godhead, but to the individual Persons of the Trinity, and are not interchangeable ( $D N$ II, 5-641 D). The unions are the hidden and inseparable supreme foundations of a permanence beyond ineffability and unknowing, while the differentiations are the benign processions and manifestations of the Thearchy (DN II, 4-640D). Differentiation can either be applied to the names given to the separate Persons ("Father", or "Son"), or to the ways of God's manifestation as being, life, wisdom etc ( $D N$ II, 5644A); there are the unified names (for the indivisible Godhead), and as a result of differentiation these flow into the world as manifestations of God, and then there are the differentiated names (the separate Persons), which are contained within the unity.

Louth laments that we cannot assess where Pseudo-Dionysius diverges from the Capadoccian tradition, as he says little about this, and refers to the lost Theological Representations, Andrew Louth, Denys the Areopagite (London-New York: Continuum, 1989), 89.

A comprehensive study on the henosis in Ysabel de Andia, Henosis - L'union à Dieu chez Denys l'Aréopagite (Leiden: Brill, 1996). 
the confusion between the Father and the Son), each of the divine persons still possesses their own characteristics, thus exemplifying the unions and differentiations "in the inexpressible unity and subsistence of God". ${ }^{16}$ The Godhead becomes differentiated in a unified way - it is multiplied and yet, remains singular, dispensed to all, remaining a unity. It is being beyond being, so it bestows existence upon everything, his single existence manifold because it brings so many things into being from itself. And yet, he remains one amid the plurality, unified throughout the procession, full amid the acts of differentiation. ${ }^{17}$

Pseudo-Dionysius is aware that the mysterious tradition of the sacred Scriptures represents the blessedness of the transcendent Deity in the form of "Being", "Mind" or "Word", showing that God is true subsistence, and cause of every being, that wisdom and rationality are his attributes, and that he is light and life. ${ }^{18}$ These sacred shapes show reverence vastly superior to anything that can be expressed for images in the world, but are as defective, for the deity is far beyond any manifestation of being and of life, and while some reference to light can help bring it to mind, every reason or intelligence falls short of similarity to it. ${ }^{19}$ The deity may be praised by being presented in utterly dissimilar revelations, like invisible, infinite, ungraspable, which basically show what it is not, observes Pseudo-Dionysius, and expresses his agreement as to the appropriateness of this method (scriptural device), for as the sacred tradition has instructed, God is in no way anything like the things that have being, nor have we got any knowledge of his incomprehensible and ineffable transcendence. ${ }^{20}$ Pseudo-Dionysius finds this way of

\footnotetext{
${ }^{16} \mathrm{DN}$ II, 5 (641D).

${ }^{17} D N$ II, 11 (649 B).

${ }^{18} \mathrm{CH}$ II, $3(140 \mathrm{C})$.

${ }^{19} \mathrm{CH}$ II, 3 (140 D).
}

${ }^{20} \mathrm{CH}$ II, 3 (141A). We can reasonably say, adds Pseudo-Dionysius elsewhere in $\mathrm{CH}$, that purification, illumination, and perfection lead to an understanding of the Godhead: by being completely purified of ignorance by the proportionately granted knowledge of the more perfect initiations, by being illuminated by the same divine knowledge (through which it also purifies whatever was not previously beheld, but is now revealed through the more lofty enlightenment), and by being perfected in the understanding of the most lustrous initiations ( $\mathrm{CH}$ VII, 3-209C-D).

The role of negative theology in the interpretation of biblical symbols is explicit in $\mathrm{CH}$ 's discussion of incongruity and dissimilarity, remarks Rorem, applied to the biblical symbols for God and for the angels, with a direct invocation of negative theology. The $E H$, however, employs the same interpretive method with regard to liturgical symbols, namely, the uplifting through the perceptible to the conceptual, but never once states that the principle of negation is at work here (even calling precise and accurate certain ritual symbols, $\mathrm{CH} 401 \mathrm{C}$ and 404B in Rorem, Pseudo-Dionysius - A Commentary, 207). Rorem wonders whether this implies that the liturgy contains only similar imagery that invites affirmation, with no component of dissimilarity that demands negation. If these symbols are not both similar and dissimilar, then the interpretive method falls apart here, and affirmations stand alone without negation, in which case, not only the method, but the corpus is split asunder, the $E H$ thus inconsistent with the rest of the corpus ( $D N$ 's occasional, but strong statements of negative theology, 
negation to be much more suitable for the divine realm - since positive affirmations can never be fitting to the invisibility of the inexpressible, manifestation through dissimilarity is much more applicable. Dissimilar shapes help demonstrate how far removed the realm of heaven is, how it transcends all materiality, he explains, warning against the misleading thinking that heavenly beings have, for example, attributes like "golden" or "glamorous" or "fiery", among those who are incapable of rising above the familiar visual representations. The use of incongruous dissimilarities wisely takes into account the human inherent tendency towards the material and the idle satisfaction by base images, encouraging the soul to rise up towards the unexplainable divinity. ${ }^{21}$

CH's discussion of dissimilarity and incongruity, and MT's explicit rationale for negations). However, the principle of negation is hard at work in some of the chapters of the $\mathrm{CH}$, where negative theology, incorporated into the method of interpreting incongruous symbols, is then applied to the biblical depictions of the angels, for example. Aware that this might seem as an enormous assumption, Rorem suggests that the same role for negative theology introduced in the opening chapters of $\mathrm{CH}$, and implicitly understood thereafter, could perhaps be as simply presupposed in $E H$ and in its interpretation of liturgical symbols. There are many signs that in $E H$ Pseudo-Dionysius did not violate his own commitment to subject to thorough interpretation all perceptible symbols (which saves the corpus from a suspected inconsistency).

About the superfluity of the system of hierarchies, Fisher is aware that Dionysius certainly hierarchises reality, which cannot be doubted. However, he also makes it quite plain, Fisher states, that God does not fit anywhere into this hierarchy, thereby rendering the hierarchies themselves contingent (technically anarchic), and radically so, because God is not a res which they might therefore signify. There is an intelligible signified, but no Intelligible Signified; the intelligible signified is another signifier of the non-intelligible, he claims - Jeffrey Fisher, "The Theology of Dis/similarity: Negation in Pseudo-Dionysius", The Journal of Religion, Vol. 81, No. 4 (Oct., 2001): 546.

${ }^{21} \mathrm{CH}$ II, 3 (141C). He ends this passage with the reminder that that there is nothing which lacks its own share of beauty, for as Scripture rightly says, "Everything is good". Fisher directs our attention to the fact that Pseudo-Dionysius undercuts the absoluteness of negative methodologies with a line about all things being good - here gesturing to the system of which negative theology is still a part. Negative theology, Fisher expands, succumbs to (affirmative) theology precisely when it allows itself to take affirmative theology's place. A positive negativity, in other words a negativity that never succumbs to its own negativity, ultimately yields to the affirmative. A positive negativity is not a negativity; it is the positive under the guise of the negative. In order for the negative to be negative, it must disappear into itself. So far, it all seems logically sound. However, Fisher continues, demanding of Pseudo-Dionysius methodology something that is not its purpose. Negation demands a return to affirmation, Fisher writes, in order to indefinitely defer an affirmative victory. Only in losing does the negative win, because it is in/by losing that it indicates its own vulnerability, its own risk of affirmation, and in that indication, it indicates a beyond which is beyond its ability to indicate. Moreover, in its willingness to negate itself, it risks absolute negation - a fall into nothingness, Fisher, "The Theology of Dis/similarity: Negation in Pseudo-Dionysius", 540. This is logically sound, but not applicable to Pseudo-Dionysius' theology, as he clearly does not advance passive nihilism, or resignation. Negations for the One which cannot be known are a good way towards suitable un-knowledge, this isn't defeatism, but active experiencing of a limitless God. Anyway, there is a clear way out 
What the sacred scriptures tell regarding the divine names refers to the beneficent processions of God, so they praise him as a monad (because of his supernatural simplicity, or indivisible unity) ${ }^{22}$, or a Trinity (because it is manifested as "three persons"), or Cause of beings (since its creative power summons all things into being), and wise and beautiful (because beings are filled with divine harmony and holy beauty). ${ }^{23}$ God has also extended courtesy to man's lowly state to rise up to him - in a manner beyond words, the simplicity of Jesus became complex, he came into human nature, albeit totally transcending the natural order of the world. In this Pseudo-Dionysius funds divine enlightenment into which we have been initiated by the "hidden tradition of our

of this, and Fisher acknowledges this, as shall be shown later, through PseudoDionysius' hyper-negation in $M T$.

${ }^{22} \mathrm{DN}$ I, 4 (589D).

${ }^{23}$ DN I, 4 (592A-B). Rorem notices (see footnote 10 in Luibheid, Pseudo-Dionysius: the Complete Works) that this description of movement from monad to triad to the cause of all creation to the one who became incarnate in the created realm of space and time (589D to 592B) is presented as a downward procession from simplicity to plurality. He suggests that since MT III (1032 D to 1033A) presents a similar descending trajectory as a summary of the Theological Representations, the DN might be summarising a treatise that was never actually written. In $D N$ it is perhaps mentioned in 1589038 to 592B 17, again in I (593B), DN II (636C), 640B, 20-24, 644 D-645A, and $D N$ XI 953B 17-20. Vanneste has argued for a major division within the Dionysian corpus between $M T$ and the $D N$ on the one hand, and the two Hierarchies on the other (Vanneste, Le mystère de Dieu, 30-36). Rorem in Luibheid suggests that in an alternative argument, $M T$ first summarises the preceding $D N$, and then previews the methods of interpretation of biblical symbols and the liturgy, developed in the hierarchical treatises (Luibheid, Pseudo-Dionysius: the Complete Works, 133).

On the subject of reality of names, Mortley reminds us that Pseudo-Dionysius' theory on names derives from the Parmenides and therefore tends to establish not the validity of these names, but their existence, Raoul Mortley, From Word to Silence, Vol. II (Bonn: Hanstein, 1986), 229. They are present to the minds as realities. He has, therefore, the further task to show how these eponyms for the Forms can be applied to God, and (for the most part) he chooses to do this by what might be called the way of positive negation: by establishing firstly the existence of the name ("great", as derived from Greatness itself, for example), he then proceeds to show that God is more than great, that his transcendence is not great in the sense that it is more great than greatness. It is clear that his theory of names provides a strong endorsement of theological language, with its ontic grounding as outlined, and in this sense Pseudo-Dionysius is very positive about language, which, when conceived this way, might seem as a surprising conclusion to draw about the figure who is, after all, the archetypal Christian exponent of the via negativa. For him names are real, and may be sourced to the Real itself, asserts Mortley.

On the subject of terms used in the $D N$ and later denied in the $M T$, in a logical deconstruction of oppositions, Tomasic finds that one of the foremost and striking logical oddities found in the Pseudo-Dionysius is the constant contrapositioning or conjuncting what apparently are collision terms and statements. If, for example, one read the $D N$ and the $M T$ as a single piece, as it would appear they were meant to be read, one is struck by their mutual opposition: positive claims in the first are denied in the second, Thomas Michael Tomasic, "The Logical Function of Metaphor and Oppositional Coincidence in the Pseudo-Dionysius and Johannes Scottus Eriugena", The Journal of Religion, Vol. 68, No. 3 (Jul., 1988): 364. 
inspired teachers" (later substitutes it with "hierarchical traditions"), which is at one with Scripture (it is unclear what precisely he means by this hidden tradition, as he usually mentions the theological tradition of yore, which is revealed), so that we can grasp things as much as we can. ${ }^{24}$ The Transcendent is, as he puts it, clothed in the terms of being, with shape and form on things which have neither. To convey the attributes of what has no image, but has supra-natural simplicity, various symbols are employed. In time, human minds will be like those in the heavens above, grants Pseudo-Dionysius, and we shall be equal to angels and sons of God (following the formulations from Scripture), but for now, we use whatever appropriate symbols we can find for the things of God, analogies to help guide the mind upwards, leaving behind our own notions of the divine, thus approaching that which transcends being. ${ }^{25}$ Pseudo-Dionysius inserts ineffability again: in that rapprochement to the transcendent, in a manner that escapes words, all the goals of all knowledge preexisted. It cannot be contemplated, as it is fully beyond the capacities of comprehension. Neither intelligence nor speech can grasp it, as "transcendently it contains within itself the boundaries of every natural knowledge and energy". Since the Transcendent is established by an unlimited power beyond all the celestial minds, in a perfectly logical flow, Pseudo-Dionysius concludes that, if all knowledge is of that which is, limited to the realm of the existent, then whatever transcends being must also transcend knowledge. ${ }^{26}$

The question arises, Pseudo-Dionysius notes, on the problem of theological language, namely, the possibility to speak of divine names. The transcendent surpasses all being, all knowledge, it encompasses and circumscribes all things, anticipates all things while eluding their grasp, escaping any perception, opinion, name, apprehension, discourse, understanding, so we cannot enter the endeavour of naming that which is superior to being, unknowable and unnameable. ${ }^{27}$

${ }^{24} \mathrm{DN}$ I, 4 (592B).

25 Ibid.

${ }^{26} \mathrm{DN}$ I, 4 (593A). In Luibheid this is summarised as an ascent of two steps - first through perceptible symbols up to the conceptions symbolized (MT IV and the entire process of interpreting biblical and liturgical symbols in $\mathrm{CH}$ and $\mathrm{EH}$ ), then beyond every conception ( $M T \mathrm{~V}$ and the final abandonment of speech and thought, see footnote 17 in Luibheid, Pseudo-Dionysius: the Complete Works, 53).

${ }^{27} \mathrm{DN}$ I, 5 (593B). When it comes to naming names, and the methodological problems our logic and language create, it is important to always remember that the cataphatic and the apophatic theologies operate in the same field, in contrary directions, each acting as a check upon the other. This can be most clearly seen at the end of each process: the cataphatic theology as expounded in the $D N$ ends with such affirmations as "King" and "Lord", and requires the apophatic to rescue it from anthropomorphism; the apophatic ends with the negation that God is, and requires the affirmation that God is the Cause of all being and therefore cannot simply not be (logically, even the negation that $\mathrm{He}$ is, is the affirmation that he is not, Sheldon-Williams, "The Greek Christian Platonist Tradition from the Cappadocians to Maximus and Eriugena", 468). 
Pseudo-Dionysius mentions his Theological Representations, claiming that there he had stated that one can neither understand, nor discuss the superknowable Transcendent, the "Triadic Unity" ${ }^{28}$ The union of divinised minds with the Light "beyond all deity occurs in the cessation of all intelligent activity"; the minds that imitate the angels (who in a mysterious way have been deemed worthy of grasping the ungraspable) praise it through denial of all being, and supernaturally enlightened, realise that it is the cause of everything. The true seeker of truth will not praise the supra-essential being of God as word, power, mind, life or being, Pseudo-Dionysius is adamant here. ${ }^{29}$ It is completely removed from any condition, all movement, imagination, discourse, it is beyond life, name, thought, conception, unity, limit, infinity, being, the totality of existence, ${ }^{30}$ the underpinning of goodness, the cause of everything, so to praise it one must turn to all of the creation, for it is at the centre of everything. The theologians, therefore, praise it by every name, and also as the Nameless One, the wonderful name above

In his "Ineffability" Hick (see footnote 9 of this article) attempts to illustrate the fact that the distinction between, on the one hand, the Ultimate in itself, which is transcategorial, and on the other hand, its impingements on human consciousness, is found in all the main religious traditions. Although Hick allots all of three pages to PseudoDionysius in this article, Knepper expounds on Hick's take on Dionysius, avowing God's transcendence of categories by negating God's names, while at the same time maintaining that such names are metaphorically useful means of uplifting humans to God; finding that three common misunderstandings of the Dionysian corpus reside here: that the divine names are mere metaphors; that the divine names are therefore negated of God; and that the negation of divine names is the means by which humans return to and unite with God (although these misuses apply more generally, he takes Hick as "a representative of a certain type of reading of the Dionysian corpus, one that oversimplifies it to make it more serviceable to negative and comparative theological agendas", Timothy D. Knepper, "Three Misuses of Dionysius for Comparative Theology”, Religious Studies, Vol. 45, No. 2 (Jun., 2009): 207. The first misuse, according to Knepper, as Hick addresses it, is to hold that that the divine names are not literally true of God, the misuse arising from a failure to distinguish between the intelligible (which are metaphorical) and the perceptible names (causal powers which give their nature to all finite beings, Knepper, "Three Misuses of Dionysius for Comparative Theology", 208). Hick answers that he did not claim that the powers in the world were metaphors, but that it still remains a point that God transcends them, is hyper to them, and then goes on to show that while Knepper refutes God's transcategoriality, he fails to do so (Hick, "Ineffability", 224). Knepper's second misuse is to hold that 'Negation of divine names states their literal falsity of God' (Knepper, 209), to which Hick also agrees, as he said that, according to Dionysius, the divine names do not apply to God in God's ultimate transcendence either positively or negatively. Knepper's third alleged misuse is that 'Negation of divine names is not the sole or ultimate means by which humans are saved or divinized' (Knepper, 213). Hick believes that Knepper assumes that to point to Dionysius' statements that the scriptural symbols of God serve as useful means for uplifting souls, is to assert that for Dionysius this is the only or final means of salvation, to the exclusion of the Church and its rituals, which is a mistaken assumption, as Dionysius clearly had a high view of the Church (Hick, "Ineffability", 225).

\footnotetext{
${ }^{28} \mathrm{DN}$ I, 5 (593B).

${ }^{29} \mathrm{DN}$ I, 5 (593C).

${ }^{30} \mathrm{DN}$ I, 5 (593D).
} 
any other, established above any name either in this age or in ages to come, like being, life, light, God, truth. Heavily relying on chosen notions from Scripture, Pseudo-Dionysius catalogues some of the names in usage for praising the Cause of everything, which are, for lack of other options, drawn from the things caused, all sorts of fine attributes, like good, beautiful, wise, beloved, eternal, mind, word, knower, powerful, also King of Kings, God of gods, Lord of lords, Holy of Holies, Cause of the ages, possessor beforehand of all the treasures of knowledge. ${ }^{31}$

Pseudo-Dionysius writes about negative prediction, carefully explaining what it means to apply negative terms to God. Human thinking abilities are erroneous compared to the solid permanence of the perfect thoughts of God, so it is customary for theologians to apply negative terms to God, but contrary to the usual sense of a deprivation. ${ }^{32}$ Human thinking is a sort of error when compared with the solid permanence of the perfect divine thoughts, also because theologians customarily use negative terms to God, but - and this is important about his understanding of negating - contrary to the usual sense of deprivation (for example, the all-apparent light is called "invisible" in Scripture) ${ }^{33}$ He repeats several times (and refers to this previous reiteration) that we must interpret the things of God in a way that befits him. This means that when we talk of him as of a being without mind or perception, it is to be taken in the sense of what he has in superabundance, and not as a defect. Hence, the absence of reason attributed to him is because he is above reason, the lack of perfection - because he is above and before perfection. We posit intangible and invisible darkness of that Light which is unapproachable, because it exceeds all the visible light. ${ }^{34}$

Humans have the habit of seizing upon what is beyond them, not ceasing to cling to the familiar categories of their sense perceptions and reasoning, which is why they measure the divine by human standards, reminds us Pseudo-Dionysius again, thus being led astray by the apparent meaning that is given to the divine and unspeakable reason. $\mathrm{He}$

${ }^{31} \mathrm{DN}$ I, 6 (596A-B).

${ }^{32} \mathrm{DN}$ VII, 1 (865D). The One God worthy of many names is nameless and ineffable; present in all things, discoverable through all the things as inscrutable, ungraspable. Humans rely on their sense perceptions, and cannot help but measure the divine by human standards, thus giving reason to the divine and the unspeakable. Instead, suggests, Pseudo-Dionysus, we should remember that the human mind has a capacity to think, to arrive to conceptual things, but the unity through which it is joined with things beyond itself transcends the powers of the mind. See also $D N 1,6$ (596A 1-12).

${ }^{33}$ DN VII, 1 (865 B).

${ }^{34} \mathrm{DN}$ VII, 2 (869A). Here we find, observes Williams, two uses of negative terminology which seem to be mirror images of one another, insofar as the one signifies that the subject exceeds the predicate in question to the extent that the other denotes its falling-short. And the vocabulary attached to these two types of negation is "apophasis" for the negation signifying transcendence and "privation" (steresis) for the negation signifying lack, Janet Williams, "The Apophatic Theology of Dionysius the Pseudo-Areopagite - I", The Downside Review, 408 (1999): 167. 
suggests, instead, to consider that these transcending characteristics we are somewhat aware of should be given to the words that are used about God, not in the human sense. ${ }^{35}$ This is the possibility of ecstasy, as part of his teaching on henosis: in renouncing the human sense of meaning and the restraints of our points of view, we should allow ourselves to be taken wholly out of ourselves, and to become wholly of God (it is better, he adds, to belong to God, than to ourselves) ${ }^{36}$ All names are applied to God, and then God is removed from the names, as a process by which it is shown that God is, in fact, beyond them all.

Pseudo-Dionysius considers not only human (non)knowledge, but the knowledge of God, as well, which is of all things, before they even come to be. As it precontains the being of everything, as well as awareness and comprehension of everything, in terms of cause, the divine Mind does not acquire knowledge of things from them, but from itself, and in itself. This is not a knowledge of a "specific class", tries to elucidate Pseudo-Dionysius, but a "single embracing causality which knows and contains all things". ${ }^{37}$

A major question Pseudo-Dionysius tries and retries to address is that of the possibility to grasp God, who is beyond mind and senseperception, not a particular being to be known. God cannot be known in nature, he suggests to be a somewhat accurate stance, for he is unknowable and beyond mind's limits and the reach of reason. However, we can know him from the arrangement of everything, as it is all but a projection of him (what was previously mentioned about God's manifestation in the world). ${ }^{38}$ The order in the world shows some of the

${ }^{35}$ DN VII, 3 (869D).

${ }^{36} \mathrm{On}$ the achieving of ecstasy as the interpretive process of negating and moving beyond human words and symbols, see DN XIII, 4 (981B-D). This shows, comments Rorem in Luibheid, that ultimately, affirmative theology falls short. No name manages to express what God is. Thus, as in $C H$ II (and in MT), the Scriptures prefer negations since they render the soul "ecstatic", they place it outside itself. For Pseudo-Dionysius, the term "ecstasy" can carry the literal meaning of standing outside oneself, as in being drunkenly out of one's wits. This (inebriated) ecstasy, when applied to God, signifies the divine transcendence (as in Letter Nine-1112C), and the procession "downward" in a loving and creative excess of goodness ( $D N$ IV-712A). Human ecstasy is about rightly interpreting the divine manifestations ( $D N$ VII- 865D and 872D to 873A), up through negations, see footnote 266 in Luibheid, Pseudo-Dionysius: the Complete Works, 130.

${ }^{37} D N$ VII, 2 (869B). The divine wisdom knows all simply by knowing itself, but it also knows (and produces) everything by its oneness - material things immaterially, divisible things indivisibly, and plurality in a single act. God knows all things because he has perfect self-knowledge (he understands all things by understanding himself): the universal Cause knows the things that proceed from it, by knowing itself. God bestows being on everything in a causal gesture, so in that act of causation knows everything, because it both preexists in him and derives from him ( $D N$ VII, 2-869C). When he writes that the Supreme Cause of every conceptual being is not in itself conceptual (MT V-1048B), he claims that existent beings do not know it as it actually is and it does not know them as they are, though.

${ }^{38}$ Theophany is central to his understanding of God's relationship to the world - the world is a theophany, a manifestation of God, in which beings closer to God manifest 
images, or semblances, of the divine paradigms, so God can be partially known through the created world. Approaching God as far as our capacities allow us means having to pass by way of denial and the transcendence of all things, which makes him both known in all things and completely distinct from all things ${ }^{39}$ So, we do not know God in nature, but in creation. Except, we do not know him in creation either, as he is distinct from all things. He is known through knowledge and through unknowledge: there is "conception, reason, understanding, touch, perception, opinion, imagination, name, and many other things", but on the other things, Pseudo-Dionysius insists, he cannot be understood, contained in words, defined by a name.$^{40}$ God is simultaneously all things in all things, and no thing in anything; known to all from all things, and to no one from anything. This is the only type of language suitable for God, he claims, before (again) resorting to the idea of union - the most divine knowledge of God, the one that comes through unknowing, is when mind turns away from everything, even itself, and is made one with the transcendent. ${ }^{41}$

In Letter One, Pseudo-Dionysius explains about God's transcendent darkness which remains hidden from all light, concealed from all knowledge. In keeping up with the tradition of motifs of light, he matter-of-factly remarks that darkness disappears in the light, as unknowing disappears with knowledge (and the more so, as there is more), but that this does not apply to the unknowing regarding God, who escapes anyone with light and knowledge of beings. If one beholds God, and understands what one has seen, it is still not God himself, but something of his, which has being, which is knowable. He reiterates, God fully transcends both mind and being, he is completely unknown. It is important, he feels, that he expresses that God is also completely nonexistent. He exists beyond being (and so much so, that, as far as we are concerned, he has no being), and he is known beyond the mind, and "this quite positively complete unknowing is knowledge of him who is above everything that is known". ${ }^{42}$ In Letter Five, Pseudo-Dionysius further elaborates that divine darkness is the "unapproachable light" which God inhabits. It is where God should be looked upon, even though it is invisible because of it "superabundant clarity" and cannot

God to those further away through an ordered, hierarchical creation. In a departure from the Neo-Platonic tradition, Pseudo-Dionysius stipulates that being only proceeds from God or the One, and not gradually from emanations. Being itself is applicable to God in two ways: either to God himself, or to his activity in the world (Louth, Denys the Areopagite, 85-86). In Pseudo-Dionysius' trying to explain how God can be regarded both as being itself and as the source of being itself, Louth finds and example which reveals an untidiness (or, perhaps, a paradox) in Dionysian theology (Louth, 86), but is perfectly tidy if one consistently reads into the purpose of the corpus.

${ }^{39} \mathrm{DN}$ VII, 3 (872A).

${ }^{40} \mathrm{DN}$ VII, 3 (872B).

${ }^{41}$ This entire discussion on the knowledge of God through unknowing should be read with the negative approach of $M T$ and the previously referenced $C H$ II.

${ }^{42}$ Ep. I, 1065A-B. Letters One and Five comment the MT. 
be approached because it overflows with its transcendent gift of light. ${ }^{43}$ Such a worthy seeker of God, precisely because he can neither see nor know him, will arrive at that which is beyond all seeing and knowledge. This wonderful knowledge is too much to be attained (if one knows that God is beyond every act of mind and every way of knowing, one can say that he knows God). ${ }^{44}$ God's ways are inscrutable, his judgements unsearchable, his gifts inexpressible, God is found beyond all things known, surpassing any conception, the cause of all, surpassing it all. ${ }^{45}$

The Mystical Theology begins with a poem (or prayer): "Trinity, higher than any being... Lead us up beyond unknowing and light, up to the farthest, highest peak of mystic scripture, where the mysteries of God's Word lie simple, absolute and unchangeable"; this is "the brilliant darkness of a hidden silence", where mid the deepest shadow an overwhelming light is poured on what is most manifest. ${ }^{46}$ Pseudo-Dionysius' advice to Timothy, to whom he addresses, when he looks for a sight of the mysterious things, is to leave behind everything perceived and understood, everything perceptible and understandable, and all that is not, as well as all that is (that is, everything). The only way to arrive to that which is beyond being and understanding is to abandon all knowledge, oneself, ${ }^{47}$ and anything else. ${ }^{48}$ The supreme Cause of all things perceptible is not itself perceptible - it is above all, and is inexistent, lifeless, speechless, mindless. It is not material, has no shape, quality, quantity, emplacement; endures no disturbances, no deprivations, no changes, no

${ }^{43}$ Ep. I, 1073A.

${ }^{44} \mathrm{Ep} . \mathrm{V}, 1073 \mathrm{~B}$.

${ }^{45}$ Quoting Paul from Romans 11:13 and Corinthians 9:1, Phil 4:7, Ep. V, 1076A.

${ }^{46} M T$ I, 1 (997A-B). The use of "mystic" is probably not in the later sense of mystical (as in subjective extraordinary experience of transcending oneself, but in the sense of mysterious, hidden - see Louis Bouyer, "Mysticisme. Essai sur l'histoire d'un mot", Supplément de la Vie spirituelle (15 mai 1949): 3-23).

${ }^{47}$ Tomasic argues that mystical theology not only assumes a mystical anthropology, entering into "a dialectic of mutual disclosure", but actually brings it about: the negative way serves as a purgation, an asceticism, indispensable for attaining subjectivity, Thomas Michael Tomasic, Negative Theology and Subjectivity: An Approach to the Tradition of the Pseudo-Dionysius, (New York: Fordham University Press, 1969), 411, 428. Turner uses "apophatic anthropology" to describe the peculiar understanding of the human self that suffers union with the divine in prominent Dionysian descendants, Denys Turner, The Darkness of God (Cambridge: Cambridge University Press, 1995), 139-140, sqq, like Master Ekhart, 168 sqq). Stang argues that apophasis, of God and of self, is what binds together the mystical enterprise of the Dionysian Corpus, Charles M. Stang, Apophasis and Pseudonymity in Dionysius the Areopagite (Oxford: Oxford University Press, 2012), 153, and that apophatic theology necessarily entails an "apophatic anthropology", or that apophasis is best understood as a sort of asceticism that delivers a self that is as unknown as the God with whom it seeks to experience a union. For a take on apophatic anthropology in the $D N$ and the MT see Stang, 158170 .

${ }^{48}$ MT I, 1 (1000A). This introduces Moses' ascent to Mount Sinai (Vanneste, Le mystère de Dieu, 48), and in a broader sense a general anagogy beyond the perceptible, and beyond the intelligible. 
decays, no divisions, nothing of which the senses may be aware; it is neither perceived nor perceptible. ${ }^{49} \mathrm{He}$ tries to explain what can be done with he Cause of all beings, the Cause of everything - all affirmations regarding beings should be posited and ascribed to it, but more appropriately even, all these affirmations should be negated, since it surpasses all being. This does not lead to the conclusion, he warns, that the negations are simply opposites of the affirmations, but shows that the Cause of all being is both considerably prior and beyond all of this: assertions, privations and denials. ${ }^{50}$ When he recounts Moses' ascent to Mount Sinai, he stresses that it is not strictly God that Moses contemplates, but his place of dwelling - he sees this as another way of showing that anything perceived with the body or mind is but a rationale which presupposes all that lies below the Transcendent One. ${ }^{51}$ Moses breaks free from the constraints of presumptions of knowledge, and dives into the truly mysterious darkness of unknowing (perhaps better known as the 'cloud of unknowing', due to the famous later treatise of the same name), in the intangible, the invisible, thus belonging completely to him who is beyond everything. It is the way to union with the One - being neither oneself nor someone else (basically by being no one), one is supremely united by a "completely unknowing inactivity of all knowledge, and knows beyond the mind, by knowing nothing". ${ }^{52}$ If

${ }^{49}$ MT IV (1040D).

${ }^{50}$ This opposes Aristotle's stance from On Interpretation 17a. Both here and at the ending of $M T$, where insistence on negation (and not even negation) culminates in $\mathrm{V}$ $(1048 \mathrm{~B})$, the tendency to reject the impression that negations can capture the transcendent supreme Cause is clear.

${ }^{51}$ MT I, 1 (1001A).

${ }^{52} \mathrm{Ibid}$. Rorem sees chapters IV and V of $M T$ as carefully illustrating the transition from perceptible to conceptual imagery. The Dionysian ascent or return to God is essentially bipartite, with two distinct uses of the notion of negation, as summarized in chapters IV and V of The Mystical Theology: in the anagogical ascent from the body's senses to the mind's concepts in the interpretation of symbols, perceptible images are negated and transcended in order to arrive at their conceptual meaning; then these meanings and any other concepts the mind may entertain are negated and left behind as the mind and all knowledge give way to the unknowing beyond the mind and to silent union with God, a pattern in its final goal which Rorem encounters in the DN (592C$\mathrm{D}$, Rorem, Pseudo-Dionysius - A Commentary, 210). As interpreted anagogically and in accordance with Pseudo-Dionysius' negative theology, negation is part of the interpretive process, as Rorem puts it simply: the concepts thus attained are then themselves transcended and negated, in that they are abandoned as the mind ceases to function in the final approach to God (Rorem, 211). Expanded account on the anagogical movement in Paul Rorem, Biblical and Liturgical Symbols Within the Pseudo-Dionysian Synthesis (Toronto: Pontifical Institute of Medieval Studies, 1984), 99-105. Turner seems to think that the contents of these chapters fail to conform to this scheme. He takes issue, among other things, with the heterogeneous nature of the names used, failing to see them as pertaining to the same (logical) class: all the 'perceptual' names of God denied in chapter IV of $M T$ contain an intrinsic reference to something material, which is why when affirmed of God they have to be affirmed metaphorically and through their literal falsehood. Not so with the 'conceptual' names denied in the second stage of the ascent of negation, described in chapter $\mathrm{V}$, he admits, but still finds that on any 
only we could lack all sight and knowledge, he passionately hopes, so we could arrive, unseeing and unknowing, to that which lies beyond all seeing and knowledge; to see and to know would mean to deny all beings in order to praise the Transcendent One in a transcending way. To praise the Transcendent One in a transcending way, namely through the denial of all beings, would be really to see and to know (like sculptors, he illustrates, who set out to carve a statue, removing every obstacle to the pure view of the image of beauty hidden inside). ${ }^{53}$ The Supreme

account of the distinction between the 'perceptual' and the 'conceptual' some of the names listed in chapter V do not belong with the 'conceptual' (Turner, The Darkness of God, 40). Williams thinks that the ascent is not, as Rorem alleges, merely through sensible to conceptual images, but through types of negation, from the privative negation which is totally inadequate to theological expression, then progressing through the aphairetic negation which maps out the ascending dialectic of knowing and unknowing, and ending with the apophatic negation, not named, but demonstrated in the realization that this progression falls short of its aim of union (Williams, "The Apophatic Theology of Dionysius the Pseudo-Areopagite - I", 169).

${ }^{53}$ MT II (1025A-B). Vanneste (Le mystère de Dieu, 67-8) finds this image to illustrate aphairesis very suitable.

When Pseudo-Dionysius refers to The Theological Representations and The Symbolic Theology he underlines again that the more we move upward, the more our words are confined to the ideas we are capable of conceptualising, but plunging into the darkness beyond intellect means that we run out of words, and become speechless and unknowing (MT III - 1033B-C).

Just like not all affirmations concerning God are equally appropriate, nor are the negations - the attributes to be negated are arranged in an ascending order of decreasing incongruity, observes Rorem in Luibheid. This is why we move from perceptible attributes, we go from the lowest and most obviously false statements about God, moving upwards to those that may seem more congruous, and up to a complete abandonment of all speech and thought, even negations, in $M T \mathrm{~V}$ (see footnote 17 in Luibheid, Pseudo-Dionysius: the Complete Works, 140).

The word to describe any images affirmed of God, aphairesis, could mean "removal", "taking away". So, apart from the negations of privations and transcendence present scattered throughout the Corpus, there is this third type of negation, the dialectical denial of the appropriateness of images, or, as Williams puts it, otherwise envisaged as a process of abstracting obfuscating notions from our conception of the divine ("The Apophatic Theology of Dionysius the Pseudo-Areopagite - I", 167). The sculpting analogy is used to show that the negations of abstraction form a graded progression, a methodical engagement with the images offered in scripture, elucidates Williams, they constitute the anagogy of the soul towards the divine. It is the negation of aphairesis which is equal, but, opposite to theological affirmation, and which bears the soteriological priority over affirmation (Ibid.). The apophatic way is not equivalent to the way of negation. Pseudo-Dionysius' conclusion that the negations (apophaseis) are not simply the opposites of the affirmations (kataphaseis), but rather that the cause of all is considerably prior to this, beyond privations (stereseis), beyond every denial (aphairesis), beyond every assertion (thesis) from (MT 1000B), refers specifically to its last part - as Williams formulates it, the bipartite dialectic of perceptible and conceptual imagery is the realm of the aphairetic or abstractive negation; the negation of the dialectic itself is apophasis (Williams, "The Apophatic Theology of Dionysius the PseudoAreopagite - I", 168). What chapters IV and V exemplify, believes Williams (commenting on Rorem's take on them), is the triad of negations: the first negations given are denials that the divine is inexistent, lifeless, speechless, mindless, which are clearly 
Cause of everything conceptual is not in itself conceptual, insists Pseudo-Dionysius. It is not soul or mind, nor does it possess imagination, conviction, speech, or understanding. It is not speech per se, nor understanding per se, nor number, greatness (or smallness), equality or inequality, similarity or dissimilarity, nor substance, eternity, time. It has no power, and it is not power. It does not live, nor is it life. ${ }^{54}$ It is important, although so far he tried approaching a (non)knowledge of divinity, to underline that it is not divinity in the sense in which we understand the term. Furthermore, he reiterates, it cannot be spoken of and it cannot be grasped by understanding, as it is neither knowledge nor truth; there is no speaking of it, nor name or knowledge of it. The Supreme Cause is beyond assertion and denial - our assertions and denials are approximate and analogues, never of it, for it is beyond every assertion, and, by virtue of its pre-eminently simple and absolute nature, free of every limitation, and beyond every denial. ${ }^{55}$

examples of the privative negation, steresis; followed by negations about an ascent through material to increasingly abstract images of the divine, denying the validity of them all (the aphairetic denials of images from scripture), and the final comments, about God being beyond every assertion, limitation and denial effect the apophatic negation by denying the validity of these negations too (Ibid.). Rocca lists J. Williams' disagreement, when she claims that Pseudo-Dionysius makes a clear linguistic distinction between "aphairetic" and "apophatic" negations, for, as he puts it, she is referring to the MT passage, but not the $D N$ ones (Rocca, Speaking the Incomprehensible God, 16), which would be true, had her account on the matter been unsubstantiated or unclear (which it is not). Rocca, however, agrees with Williams that Pseudo-Dionysius acknowledges at least two kinds of negation (again, her point is on the fact there are more than two kinds), but he does not hold that Pseudo-Dionysius makes such a sharp linguistic separation between apophasis and aphairesis (Rocca, 16). Mortley suggests that in linking steresis, thesis and aphairesis, Pseudo-Dionysius seems to include privation as an epistemological mode, with the intention of asserting that none of the three (postulation, abstraction, privation) can be used of God. Privation from $1040 \mathrm{D}$, Mortley believes, is clearly designated to be of the sensible world, and associated with various change-of-state concepts, and states that Pseudo-Dionysius, more than any other figure in classical antiquity, tends to sever the links of privation with logic and epistemology, which is where the notion of privation as a deficient ontological state begins to form, and from where the medieval notion of privation as evil takes root (Mortley, From Word to Silence, 234).

${ }^{54} M T$ V $(1048 \mathrm{~A})$.

${ }^{55} M T$ V (1048B). As was mentioned in (footnote 21 of this article), Fisher sees the hypernegation at the end of the $M T$ as a negation not only of negation, but also of affirmation. At this point, Pseudo-Dionysius simply will brook no speech, because that of which we were attempting to speak is outside any possibility of speech (Fisher, "The Theology of Dis/similarity: Negation in Pseudo-Dionysius", 540). The risk of nihilism in this passage beyond both affirmation and negation is manifest, as is the risk of "empty formalism" described by Derrida (Fisher is on the opinion, and tries to show in his article, that Pseudo-Dionysius engages in an apophaticism of the most radical kind, and that negative theology is significantly compatible with certain aspects of Derridean deconstruction). Nevertheless, Fisher continues, when we assert what is beyond every assertion, we must then proceed from what is most akin to it; not according to the hypernegation which itself disallows any dis/similarity, and as we do so we make the affirmation on which everything else depends; and yet in proceeding from what is most 
The aim of this article was to show some aspects of PseudoDionysius' apophaticism, and by offering this brief account on his ideas on the ineffability and incomprehensibility of God, to glimpse at the vast possibilities for further interpretation and for integration of his conceptions into contemporary pluriperspective discussions of philosophy of religion, theology, philosophy of language, and of the ways of communicating faith in the modern world.

\section{BIBLIOGRAPHY}

Aristotle. Categories, On Interpretation, Prior Analytics. Cambridge: Harvard University Press, 1960.

Aristotle. Metaphysics, H. Apostle (ed.). Bloomington: Indiana University Press, 1966. Bouyer, Louis. "Mysticisme. Essai sur l'histoire d'un mot", Supplément de la Vie spirituelle (15 mai 1949): 3-23.

Carabine, Deirdre. The Unknown God. Louvain: Peeters Press, 1995.

De Andia, Ysabel. Henosis - L'union à Dieu chez Denys l'Aréopagite. Leiden: Brill, 1996.

Fisher, Jeffrey. "The Theology of Dis/similarity: Negation in Pseudo-Dionysius", The Journal of Religion, Vol. 81, No. 4 (Oct., 2001): 529-548.

Hick, John. "Ineffability", Religious Studies, Vol. 36, No. 1 (Mar., 2000): 35-46.

Knepper, Timothy D. "Three Misuses of Dionysius for Comparative Theology", Religious Studies, Vol. 45, No. 2 (Jun., 2009): 205-221.

Лосский, Владимир Н. “Апофатическое богословие в учении святого Дионисия Ареопагита", Богословские труды (1985, Но. 26):163-172.

Louth, Andrew. Denys the Areopagite. London-New York: Continuum, 1989.

Luibheid, Colm, trans. Pseudo-Dionysius: the Complete Works. New York-Mahwah: Paulist Press, 1987.

Mortley, Raoul. From Word to Silence, Vol. II. Bonn: Hanstein, 1986.

Rocca, Gregory P. Speaking the Incomprehensible God. Washington: The Catholic University of America Press, 2004.

Rorem, Paul. Biblical and Liturgical Symbols Within the Pseudo-Dionysian Synthesis. Toronto: Pontifical Institute of Medieval Studies, 1984.

Rorem, Paul. Pseudo-Dionysius - A Commentary on the Texts and an Introduction to Their Influence. New York-Oxford: Oxford University Press, 1993.

akin to it, we also necessarily proceed from what is different from it, in fact, infinitely different. Pseudo-Dionysius manages to avoid both nihilism and totalism (where he risks both) by inverting the relationship between affirmation and negation, such that, whereas the negative had been seen as relative to affirmation, affirmation is now seen to rest on a hypernegation, which indeed provides the very possibility of affirmation while simultaneously undercutting any final authority it might have (Fisher, 540). U1timate knowledge is unknowing for Pseudo-Dionysius, but Fisher grants that this does not mean that knowledge is to him unimportant, on the contrary, it is crucial in the sense that the more one attains knowledge, the more one realises that it is severely, infinitely limited. 
Sheldon-Williams, I. P. "The Greek Christian Platonist Tradition from the Cappadocians to Maximus and Eriugena", in A. H. Armstrong, Ed. The Cambridge History of Later Greek and Early Medieval Philosophy. Cambridge: Cambridge University Press, 1967, 421-505.

Tomasic, Thomas Michael. "The Logical Function of Metaphor and Oppositional Coincidence in the Pseudo-Dionysius and Johannes Scottus Eriugena", The Journal of Religion, Vol. 68, No. 3 (Jul., 1988): 361-376.

Tomasic, Thomas Michael. Negative Theology and Subjectivity: An Approach to the Tradition of the Pseudo-Dionysius. New York: Fordham University Press, 1969.

Turner, Denys. The Darkness of God. Cambridge: Cambridge University Press, 1995.

Vanneste, Jan. Le mystère de Dieu - Essai sur la structure rationelle de la doctrine mystique du Pseudo-Denys l'Aréopagite. Desclée de Brouwer: Brussels, 1959.

Williams, Janet. "The Apophatic Theology of Dionysius the Pseudo-Areopagite - I", The Downside Review, 408 (1999): 157-172. 